\title{
Initial development of the endocarp in Lithraea brasiliensis Marchand (Anacardiaceae): with taxonomic notes
}

\author{
JOÃO M.S. DE OLIVEIRA ${ }^{1}$ and JORGE E.A. MARIATH ${ }^{2}$ \\ ${ }^{1}$ Laboratório de Botânica Estrutural, Depto. de Biologia, Universidade Federal de Santa Maria/UFSM, \\ Avenida Roraima, 1000, Prédio 16, Sala 3253, 97105-900 Santa Maria, RS, Brasil \\ ${ }^{2}$ Laboratório de Anatomia Vegetal, Depto. de Botânica, Universidade Federal do Rio Grande do Sul/UFRGS, \\ Av. Bento Gonçalves, 9500, 91501-970 Porto Alegre, RS, Brasil
}

Manuscript received on August 14, 2014; accepted for publication on December 14, 2014

\begin{abstract}
Investigation into the initial developmental stages of a given structure is fundamental for precise characterization as well as for comparative analysis in relation to other taxa when homologies are established. For the Anacardiaceae family, investigations of the initial development of the pericarp or its basic histological sites, the epicarp, mesocarp and endocarp, are relevant since these regions are of taxonomic and phylogenetic importance. The initial stages of endocarp development in Lithraea brasiliensis were studied using light microscopy. In L. brasiliensis, the fruits are of the drupe type. The endocarp originates exclusively in the epidermis of the locular cavity and is composed of only three strata. The crystalliferous layer, typical in fruits of the Anacardiaceae family, originates in the carpelar mesophyll and runs adjacent to the outermost layer of the endocarp. The endocarp in Lithraea brasiliensis is of the Anacardium type. The results of the present study are important for the identification of the Lithraea species that occur in the state of Rio Grande do Sul. In L. molleoides, the crystalliferous layer was shown to originate from the locular epidermis and this developmental aspect enables it to be differentiated from L. brasiliensis and demonstrates that there is variability of endocarp development in Lithraea.
\end{abstract}

Key words: Anacardioideae, crystalliferous layer, endocarp, Lithraea.

\section{INTRODUCTION}

Over the last three decades, much attention has been given to the study of the pericarp structure in Anacardiaceae, since the structure - especially that of the endocarp - has great taxonomic and phylogenetic value (von Teichman 1989, Wannan and Quinn 1990, Wannan 2006). Within this context, studies on the origin and development of the mesocarp and endocarp were important for establishing their homologies (von

Correspondence to: João Marcelo Santos de Oliveira

E-mail:1inneau@yahoo.com.br
Teichman and Robbertse 1986, von Teichman 1987, von Teichman and van Wyk 1991, Carmello-Guerreiro and Paoli 2002, 2005). Considering the taxonomic importance of the anatomical traits of the pericarp, studies on its development help establish intergeneric relationships and also support the subfamilies Spondioideae and Anacardioideae (Wannan 2006). Anacardioideae is defined phylogenetically by the occurrence of a single synapomorphy on the floral structure, even though a number of its genera present an endocarp with a few layers (Wannan 2006). 
Genera such as Rhus, Schinus and Lithraea, among others belonging to the Anacardioideae subfamily, present common pericarp characteristics, such as exocarp sensu lato, parenchymatous mesocarp with secretory cavities or ducts and endocarp sensu stricto with few cell layers, which are usually sclerified (Wannan and Quinn 1990, Wannan 2006, Pell et al. 2011). However, there is variability among genera in terms of the number of endocarp layers and occurrence of the crystalliferous layer (Wannan and Quinn 1990, Carmello-Guerreiro and Paoli 2002, 2005, Wannan 2006). Rhus possesses 35 species (Pell et al. 2011), although endocarp structural details have only been described for only three of these (von Teichman 1989, Wannan and Quinn 1990). Similarly, Schinus possesses 27 species (Barkley 1957) but endocarp descriptions have been reported for only two (Wannan and Quinn 1990, Carmello-Guerreiro and Paoli 2002), while Lithraea possesses four species (Barkley 1962) and endocarp descriptions have been reported for two of these species, L. brasiliensis and L. molleoides (Pienaar and von Teichman 1998, Carmello-Guerreiro and Paoli 2005). This reveals that although descriptions of pericarp structure and development are considered to possess 'pronounced diagnostic significance,' there is little knowledge available for a large number of Anacardiaceae species (von Teichman 1989). Therefore, the use of the pericarp traits, or of its layers, is not explored in favor of species circumscription or identification.

Thus, the present study intends to demonstrate the initial development of the endocarp in Lithraea brasiliensis, in order to improve the characterization of the species and look at the taxonomic application of developmental and structural characteristics related to the endocarp.

\section{MATERIALS AND METHODS}

Floral buds in different stages of development, flowers in anthesis, and young fruits of Lithraea brasiliensis Marchand, were collected in the municipality of Porto Alegre, state of Rio Grande do Sul, Brazil. Voucher material was deposited at the ICN Herbarium under registration 127151. The material was fixed in $1 \%$ glutaraldehyde and $4 \%$ formaldehyde, in a phosphate buffer $0.1 \mathrm{M}$ with a pH of 7.4 (McDowell and Trump 1976). Later, the material was dehydrated in an ethylic alcohol series and embedded in (2-hydroxyethyl)methacrylate (HEMA) (Gerrits and Smid 1983). The blocks were cut into sections in a sliding microtome (Leitz 1400), with $5 \mu \mathrm{m}$ thickness, and in an ultramicrotome (Leica Ultracut UCT), with $1 \mu \mathrm{m}$ thickness, equipped with a glass knife. Toluidine Blue $\mathrm{O}$, in sodium benzoate buffer with a $4.4 \mathrm{pH}$ (Feder and O'Brien 1968), was used for staining. The observations and photomicrographs were performed using bright field and polarized light under Leica DM2000 light microscope with a DFC 295 digital camera.

\section{RESULTS AND DISCUSSION}

Lithraea brasiliensis fruits are of the drupe type (Fig. 1A), possessing chartaceous, brittle and detachable exocarp, multilayered and resinous mesocarp, and bony endocarp (Pell et al. 2011). The differentiation of the endocarp begins from the locular epidermis, which is unistratified and continues with the epidermis that covers the ovule. Continuity between the locular epidermis and the ovule epidermis was observed, since the early stages of development (Fig. 1B). This homology between the locular and ovule epidermis occurs because both tissues originate from the outermost layer of the floral meristem.

The periclinal divisions that form the endocarp strata begin before anthesis. In this developmental stage, it is found that in the placentation region, the locular epidermis presents isodiametric cells (Figs. 1C-D), while the ovule epidermis presents bulky cells that can accumulate large amounts of phenolic compounds (Figs. 1D, 2A-B). Only two cycles of periclinal divisions in the locular epidermis occur 

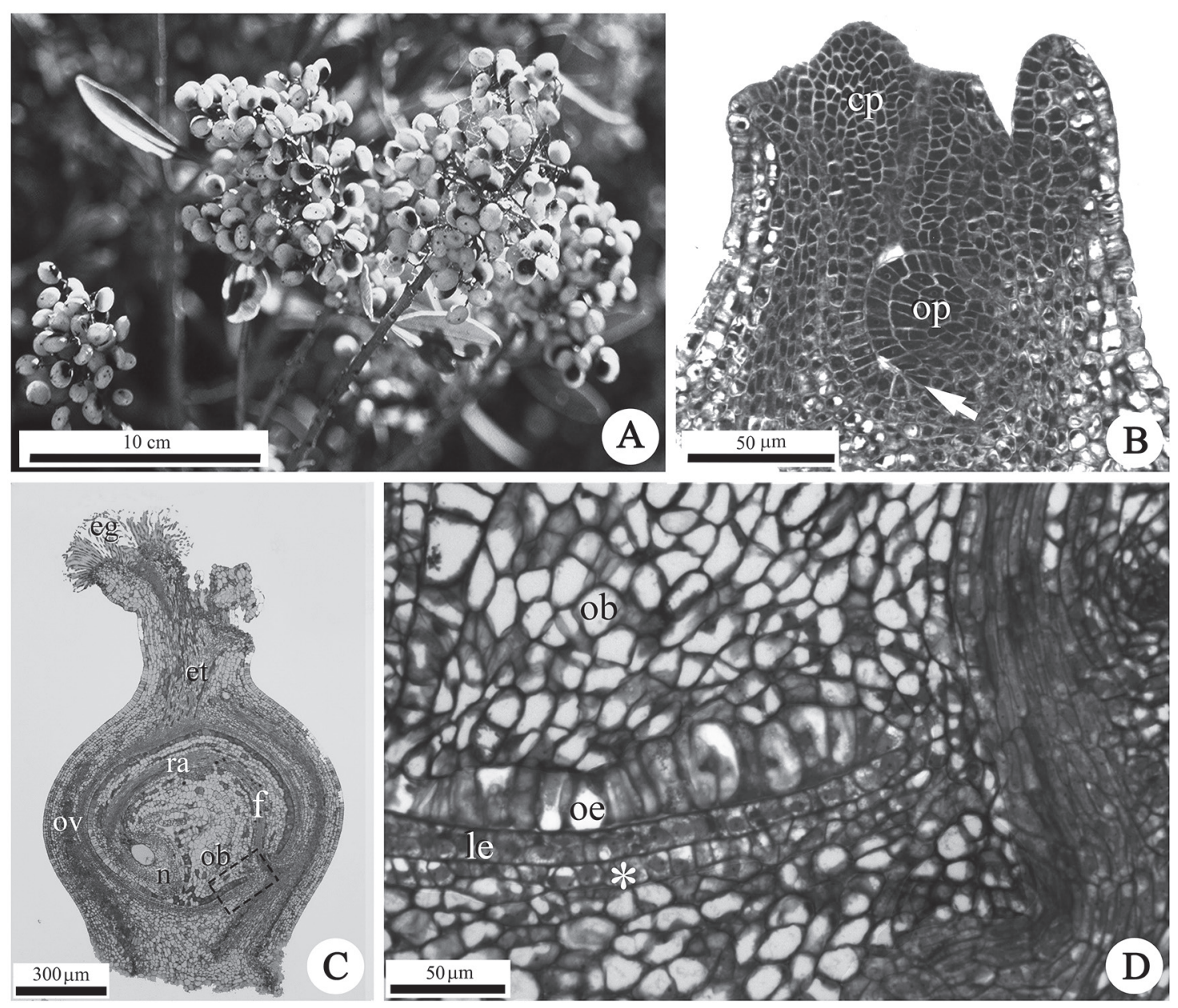

Fig. 1 - Morphology and anatomy of fruits and flowers of Lithraea brasiliensis Marchand. A. Photomacrograph of the ripe fruits. B, D-G. Longitudinal sections of flowers and fruits at different developmental stages. B. Detail of an immature gynoecium during the emergence of the ovule. Arrow indicates the limitrophe point between the locular protoderm and the protoderm of the ovular primordia. C. Pre-anthesis floral bud. Frame indicates the placental region, the place for detailed analysis of the differentiation of the layers of the endocarp in Figure D and Figures 2A to C. D. Pre-anthesis floral bud. Locular epidermis is one layered. Crystalliferous layer (asterisk). cp = carpel primordial; eg = stigma; et $=$ style; $\mathrm{f}=$ funiculus; $\mathrm{le}=$ locular epidermis; $\mathrm{n}=$ nucellus; $\mathrm{ob}=$ funicular obturator; oe $=$ ovular epidermis; op = ovule primordia; ov = ovary; $r a=$ raphe.

to form the endocarp, culminating in an endocarp with three strata (Figs. 1D, 2A-B), where cells are sclerified at maturity and appear as a functional unit (Fig. 2D), which is classified as an endocarp sensu stricto (Roth 1977). The crystalliferous layer, therefore, is part of the mesocarp (Figs. 1D, 2A-E). Because of its development and resulting structure, the endocarp in Lithraea brasiliensis belongs to the Anacardium type, typical in the clade A2 of the Anacardioideae subfamily, which includes
Astronium, Cotinus, Euroschinus, Rhodosphaera, Schinus, Schinopsis and Toxicodendron (Wannan 2006), all of which are taxa with Anacardium type endocarp (Wannan and Quinn 1990, CarmelloGuerreiro and Paoli 2002, 2005) and, therefore, very similar to that described in this study.

In Schinus molle, the ontogenetic data presented by Copeland (1959), show an endocarp with only three strata, similar to that reported for species of Toxicodendron diversiloba (Copeland and Doyel 
1940) and Rhus problematodes (von Teichman and van Wyk 1991). In Schinus areira (Wannan and Quinn 1990) and in Lithraea molleoides (CarmelloGuerreiro and Paoli 2005), researchers described the initial development and differentiation of the endocarp, where it was demonstrated that the crystalliferous layer originates from the locular epidermis. Pienaar and von Teichman (1998) indicated the crystalliferous layer in L. brasiliensis as belonging to the endocarp, however this was based on the endocarp structure in Rhus lancea (von Teichman and Robbertse 1986). In Rhus lancea (von Teichman and Robbertse 1986), the crystalliferous layer was found to originate from the locular epidermis based on the mode of alignment of its cells with cells from the innermost layers of the pericarp, which would indicate cell division. In the present study, the evidence of cell division in the locular epidermis, in light of the fact that no cell division occurs in the locular epidermis, is considered to be fundamental for determining that the crystalliferous layer does not originate from the locular epidermis.

In addition, we consider the crystalliferous layer, a typical tissue in different Anacardioideae genera, to be an example of cell differentiation that is related to its position. In other words, the accumulation of crystals is related to differentiation of the adjacent endocarp and to its relatively high metabolic demand, as a function of the large increase of cellulose in the taxa in which sclerification occurs. A number of examples support this hypothesis, such as the absence of crystalliferous deposits adjacent to the endocarp in species in which its sclerification does not occur, such as Mauria biringo and Parishia maingayi (Wannan and Quinn 1990), or the presence of a crystalliferous layer in taxa such as Mangifera and Swintonia, which present a sclerified endocarp (Wannan and Quinn 1990), despite being relatively distant phylogenetically from Lithraea, Schinus, Rhus and Euroschinus (Wannan 2006) or, finally, as in Loxostylis alata where crystals accumulate on one of the sclerified layers of the endocarp (Wannan and Quinn 1990). An additional observation that is important to note in relation to endocarp sclerification is that crystalliferous formation was delayed in Lithraea brasiliensis (Figs. 2D-E), not being observed during the initial differentiation stages (Figs. 1D, 2A-C), which has also previously been observed in other species (von Teichman and Robbertse 1986, Carmello-Guerreiro and Paoli 2002, 2005).

Thus, it is necessary to knowledge that the crystalliferous layer together with three sclerified layers is a plesiomorphic condition for the endocarp in Anacardioideae taxa (Wannan and Quinn 1990). Apparently, the combined occurrence of a crystalliferous layer and sclerified layers is not related to a phylogenetic condition via a developmental pattern, but to the storage of ergastic substances that result from the metabolism, which is influenced by the position of the cells in the organ. This finding dissociates crystalliferous layer formation from endocarp developmental patterns.

Therefore, when Lithraea brasiliensis and $L$. molleoides are compared, the subtle differences in the endocarp structure are useful in characterizing and identifying each species, especially in the central region of the state of Rio Grande do Sul, where the species are sympatric and present a morphological superposition of their vegetative and floral characteristics (Fleig 1987). Cabrera (1938, 1939) reported L. brasiliensis and L. molleoides to be so close that the former could be considered a variety of the latter. Barkley (1962), in a review of the Lithraea genus, indicated the difficulty to distinguish between the two and also reported problems related to determining species of different origins in tropical regions, where variability in Lithraea is common. In this sense, we consider the utilization of pericarp anatomy to be useful in the characterization and identification of Lithraea species in different geographic regions. 

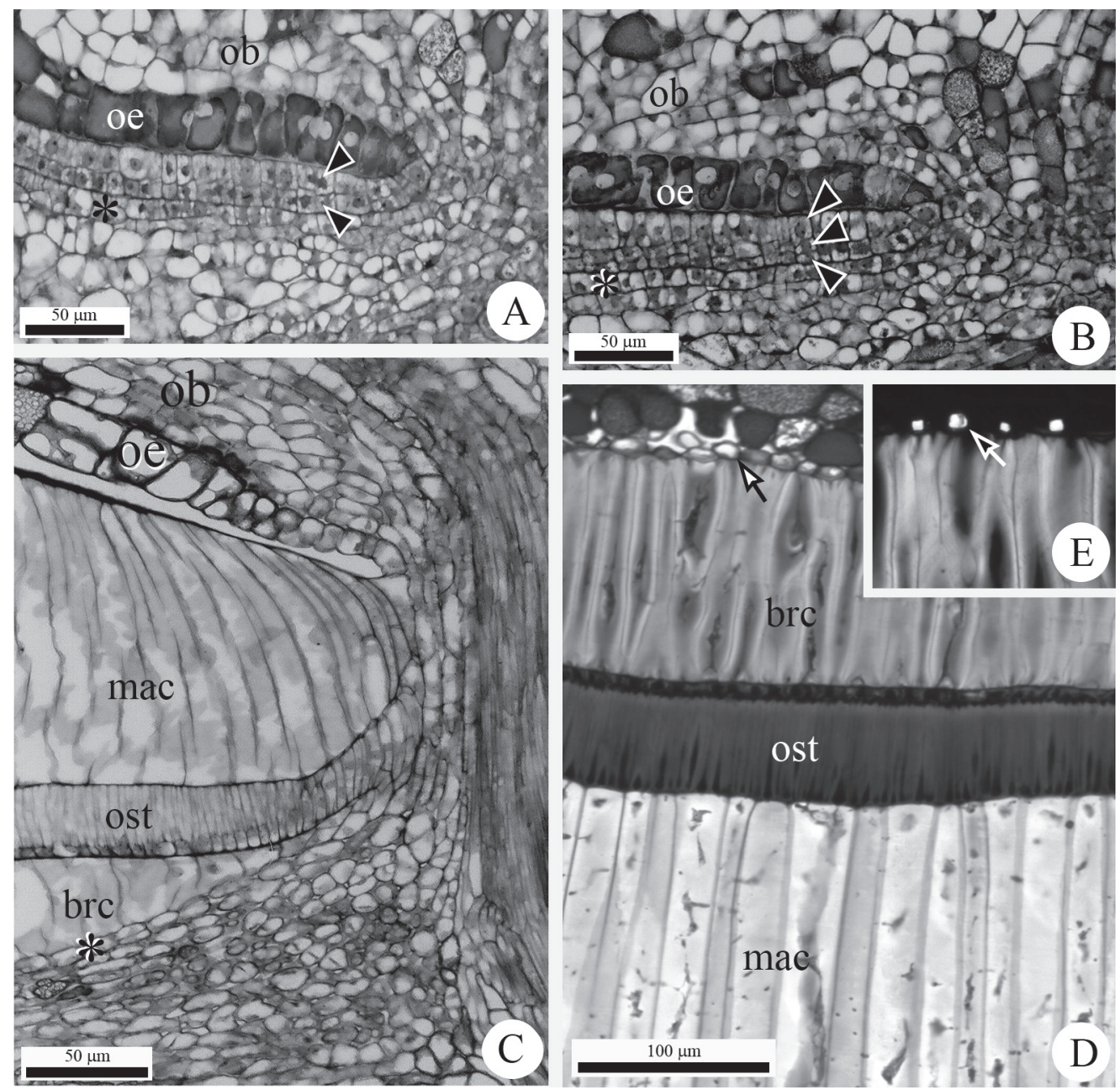

Fig. 2 - Anatomy of flowers and fruits of Lithraea brasiliensis Marchand. A. Endocarp with two cell layers (arrowheads). B. Endocarp with three cell layers (arrowheads). C. Intermediate stage of endocarp development. D. Detail of the endocarp and crystalliferous layer (arrow) in ripe fruits. E. Detail of crystalliferous layer, shown in $\mathbf{D}$, after polarized light. Crystal indicated by the arrow. Crystalliferous layer (asterisk). ob = funicular obturator; oe = ovular epidermis; mac $=$ macrosclereids; ost $=$ osteosclereids; brc $=$ brachysclereids.

As Lithraea possesses only four species, it is being better understood in relation to other larger genera in terms of pericarp development, and mainly endocarp development. It is important to highlight that L. brasiliensis and L. molleoides, despite being very close phylogentetically, were found to differ in endocarp development. Thus, generalizations related to endocarp structure in Anacardiaceae may hinder the adequate establishment of phylogenetic relations in this group.

\section{RESUMO}

O estudo do desenvolvimento inicial de uma determinada estrutura é fundamental para sua precisa caracterização e análise comparada a outros táxons, quando são estabelecidas homologias. Para a família Anacardiaceae, estudos sobre o desenvolvimento inicial do pericarpo ou de seus sítios histológicos básicos, epicarpo, mesocarpo e endocarpo, se mostram relevantes, pois tais regiões possuem importância taxonômica e filogenética. O desenvolvimento inicial do endocarpo em Lithraea 
brasiliensis, foi estudado por meio de microscopia de luz. Em L. brasiliensis, os frutos são do tipo drupa. $\mathrm{O}$ endocarpo se origina exclusivamente da epiderme da cavidade locular e é composta por apenas três estratos. A camada cristalífera, típica nos frutos da família Anacardiaceae, possui origem no mesofilo carpelar e ocorre adjacente a camada mais externa do endocarpo. O endocarpo em Lithraea brasiliensis é do tipo Anacardium. Os resultados do presente estudo são importantes para a identificação das espécies de Lithraea que ocorrem no estado do Rio Grande do Sul. Em L. molleoides foi demonstrado que a camada cristalífera surge da epiderme locular e este aspecto do desenvolvimento permite diferenciá-la de L. brasiliensis e que existe, portanto, variabilidade associada ao desenvolvimento do endocarpo em Lithraea.

Palavras-chave: Anacardioideae, camada cristalífera, endocarpo, Lithraea.

\section{REFERENCES}

BARKLEY FA. 1957. A study of Schinus L. Lilloa 28: 1-110.

BARKLEY FA. 1962. Anacardiaceae, Rhoideae, Lithraea. Phytologia 8: 329-365.

CABRERA AL. 1938. Revisión de las Anacardiáceas austroamericanas. Revta del Museo de la Plata 6: 2-64.

CABrera AL. 1939. Sinopsis de las Anacardiáceas Argentinas. Rev Argent Agron 6: 85-113.

CARMELlO-Guerreiro SM AND PAOLI AAS. 2002. Ontogeny and structure of the pericarp of Schinus terebinthifolius Raddi (Anacardiaceae). Braz Arch Biol Tech 45: 73-79.

CARMello-Guerreiro SM AND PAOLI AAS. 2005. Ontogeny and structure of the pericarp and seed-coat of Lithraea molleoides Vell. Engl. (Anacardiaceae) with taxonomic notes. Braz Arch Biol Tech 48: 599-610.
COPELAND HF. 1959. The reproductive structures of Schinus molle (Anacardiaceae). Madroño 15: 14-25.

Copeland HF AND Doyel BE. 1940. Some features of the structure of Toxicodendron diversiloba. Am J Bot 27: 932-939.

FEDER N AND O'BRIEN TP. 1968. Plant microtechnique: some principles and new methods. Am J Bot 55: 123-142.

FLEIG M. 1987. Anacardiaceae: Floral Ilustrada do Rio Grande do Sul. B Inst Bioc 42: 1-72.

GERRITS PO AND SMID L. 1983. A new, less toxic polymerisation system for the embedding of soft tissues in glycol methacrylate and subsequent preparing of serial sections. J Microsc 132: 81-85.

MCDOWELl EM AND TRUMP B. 1976. Histological fixatives for diagnostic light and electron microscopy. Arch Pathol Lab Med 100: 405-414.

Pell SK, Mitchell JD, Miller AJ AND Lobova TA. 2011. Anacardiaceae. In: KUBITZKI K (Ed), The Families and Genera of Flowering Plants. Eudicots: Sapindales, Cucurbitales, Myrtaceae, Berlin: Springer, p. 7-50.

PIENAAR ME AND VON TEICHMAN I. 1998. The generic position of Lithraea brasiliensis Marchand (Anacardiaceae): evidence from fruit and seed structure. Bot J Linn Soc 126: 327-337.

Rотн I. 1977. Fruits of Angiosperms. Berlin: Gebrüder Borntraeger, $675 \mathrm{p}$.

VON TEICHMAN I. 1987. Development and structure of the pericarp of Lannea discolor (Sonder) Engl. (Anacardiaceae). Bot J Linn Soc 95: 125-155.

VON TEICHMAN I. 1989. Reinterpretation of the pericarp of Rhus lancea (Anacardiaceae). S Afr J Bot 55: 383-384.

Von TEICHMAN I AND RobBertse PJ. 1986. Development and structure of the pericarp and seed of Rhus lancea L. fil. (Anacardiaceae), with taxonomic notes. Bot J Linn Soc 93: 291-306.

VON TEICHMAN I AND VAN WYK AE. 1991. Taxonomic position of Rhus problematodes (Anacardiaceae): evidence from fruit and seed structure. S Afr J Bot 57: 29-33.

WANNAN BS. 2006. Analysis of generic relationships in Anacardiaceae. Blumea 5: 165-195.

WANNAN BS AND QUINN CJ. 1990. Pericarp structure and generic affinities in the Anacardiaceae. Bot J Linn Soc 102: $225-252$. 